Jurnal Belantara Vol. 4, No. 2, Agustus 2021 (195-206)

E-ISSN 2614-3453

DOI: $\underline{10.29303 / \mathrm{ibl} . v 4 \mathrm{i} 2.753}$

P-ISSN 2614-7238

Terakreditasi (SK No.148/M/KPT/2020)

\title{
GUILD PAKAN KOMUNITAS BURUNG DI KEBUN RAYA LIWA KABUPATEN LAMPUNG BARAT
}

Feeding Guilds of Bird Community in Liwa Botanical Gardens, West Lampung Regency

\author{
Abdurrahman Rofiq ${ }^{\star}$, Sugeng P Harianto, Dian Iswandaru, Gunardi DW \\ Jurusan Kehutanan, Fakultas Pertanian, Universitas Lampung \\ Jln. Prof. Dr. Soemantri Brojonegoro No. 1 Gedung Meneng, Bandar Lampung \\ *Email : abdurrahmanwafig@gmail.com
}

Diterima: 02/121/2020, Direvisi: 05/07/2021, Disetujui: 06/07/2021

\begin{abstract}
The vegetation on Liwa Botanical Gardens is used by several types of birds as a place of rest, sleep, nest and forage. This study was purposely done to classify bird species based on feed group / guild type. The method used in this research is point count. The bird species data obtained were grouped based on the feed guild which was divided into 6 types of guilds including, insectivoree, carnivoree, frugivore, granivoreee, nectarivoreous, and omnivoree. Each species only have one guild type, as many as 41 species of birds were found in Liwa Botanical Gardens, which was dominated by frugivores.
\end{abstract}

Keywords: bird, Liwa Botanical Gardens, guild, feed

\begin{abstract}
ABSTRAK
Vegetasi yang ada di Kebun Raya Liwa dimanfaatkan oleh beberapa jenis burung sebagai tempat istirahat, tidur, bersarang, dan mencari makan. Tujuan dari penelitian ini adalah untuk mengelompokkan jenis burung berdasarkan kelompok pakan/tipe guild. Metode yang digunakan pada penelitian ini adalah point count. Data jenis burung yang diperoleh dikelompokkan berdasarkan guild pakan yang terbagi menjadi 6 tipe guild yaitu insectivore, carnivore, frugivor, granivoree, nectarivore, dan omnivore. Setiap spesies hanya dapat memiliki satu tipe guild. Ditemukan sebanyak 41 jenis Burung di Kebun Raya Liwa yang di dominasi oleh burung-burung pemakan buah (frugivor).
\end{abstract}

Kata kunci: burung, Kebun Raya Liwa, guild, pakan

\section{PENDAHULUAN}

Secara global keanekaragaman burung di Indonesia menempati urutan keempat negara terkaya di dunia (Iskandar et al., 2019; Iswandaru et al., 2020). Menurut Birdlife (2020), jenis burung di indonesia mengalami peningkatan jumlah jenis, pada tahun 2019 dari 1777 jenis menjadi 1794 jenis pada tahun 2020. Secara ekologis, burung memegang peranan penting dalam hutan, dan wilayah lain yang tumbuh secara alami maupun buatan. Salah satu peran burung adalah menjaga fungsi dan keseimbangan ekosistem hutan (Rahmati, 2018; Maulany et al.., 2019, Tesfahunegry et al., 2016; Kiros et al., 2018; Iswandaru et al., 2020) seperti 
bioindikator lingkungan untuk melihat apakah kawasan tersebut sesuai untuk suatu organisme atau tidak (Bachri et al., 2020), sebagai polinator dan penyebar biji (Kamal, 2018), dan antimikroba (Rahmayanti dan Nuroini., 2019). Menurut Sultika et al.,(2017), tipe habitat, struktur vegetasi, adaptasi, dan seleksi alam sangat memengaruhi persebaran burung. Persebaran burung juga berkaitan dengan ketersediaan pakan (Ahadi dan Ali, 2018), sehingga jika vegetasi berkurang akan menyebabkan hilangnya sumber pakan bagi burung (Firdaus et al., 2014). Menurut penelitian yang dilakukan di Gunung Pinang Oleh Muhammad, et al. (2018), salah satu parameter yang dapat digunakan untuk melihat keutuhan ekosistem dan kualitas lingkungan dari masing-masing peran dalam rantai makanan yang terlihat pada kelompok pakan (feeding guild) burung. Kelompok pakan dapat menggambarkan posisi burung dalam rantai makanan (Novarino et al., 2008; Olabamiyo dan Akinpelu 2015).

Salah satu tempat wisata edukasi di Provinsi Lampung adalah Kebun Raya Liw (KRL) dengan luas luas 86 ha (Kebun Raya Liwa, 2017). KRL memiliki potensi sehingga dapat menjadi habitat yang sesuai untuk burung karena memiiki banyak jenis tumbuhan dan tanaman. Berdasarkan pengamatan di lapangan tumbuhan yang paling banyak dijumpai adalah pohon pulai dan baobab, tumbuhan semak seperti beluntas, alang - alang, paku andam, ki tenjo, dan loleba (Sari et al., 2020). KRL dibagi dalam beberapa blok spesies tumbuhan diantaranya taman hias, taman buah, kebun buah, plaza aren, taman bermain, taman araceae, blok loleksi, tanaman obat dan sungai (Wulandari et al., 2019).

Vegetasi yang ada di KRL dimanfaatkan oleh beberapa jenis burung sebagai tempat istirahat, tidur, bersarang, dan mencari makan. Menurut penelitian yang telah dilakukan oleh Sari (2020), saat pengamatan dijumpai banyak burung sedang bertengger, bersuara, makan, dan berlindung pada pohon pulai. Pohon pulai menyediakan biji yang merupakan pakan burung seperti perkutut, uncal buau, dan punai gading. Pada penelitian sebelumnya, ditemukan 15 spesies burung yang ada di KRL. Kemudian dari data tersebut dapat dijadikan sebagai langkah awal untuk mengembangkan kegitan birdwatching (Hasibuan et al.,2018). Sangat penting melakukan monitoring keanekaragaman jenis burung dan kondisi habitatnya dalam rangka perlindungan dari ancaman dan kerusakan habitat dari burung tersebut (Winara, 2016; Iswandaru et al., 2018). Penelitian ini bertujuan untuk mengetahui jenis burung berdasarkan kelompok pakan/tipe guild. Oleh karena itu, penelitian ini penting dilakukan sebagai bagian dalam upaya pengelolaan dan pengembangan kawasan $K R L$ sebagai objek wisata edukasi agar lebih optimal.

\section{METODE}

Penelitian ini dilaksanakan di Kebun Raya Liwa (KRL), Kota Liwa, Kabupaten Lampung Barat, Provinsi Lampung, selama bulan April 2020. Peralatan yang digunakan dalam penelitian ini antara lain tally sheet, binokuler, jam tangan, perekam suara, kamera Canon DSLR, kompas, dan buku panduan lapangan identifikasi jenis burung seri "Panduan Lapangan Identifikasi Jenis Burung di Sumatera, Jawa, Bali dan Kalimantan". Bahan yang digunakan sebagai objek penelitian yaitu jenis burung yang berada di KRL. Peta lokasi dapat dilihat pada Gambar 1. 


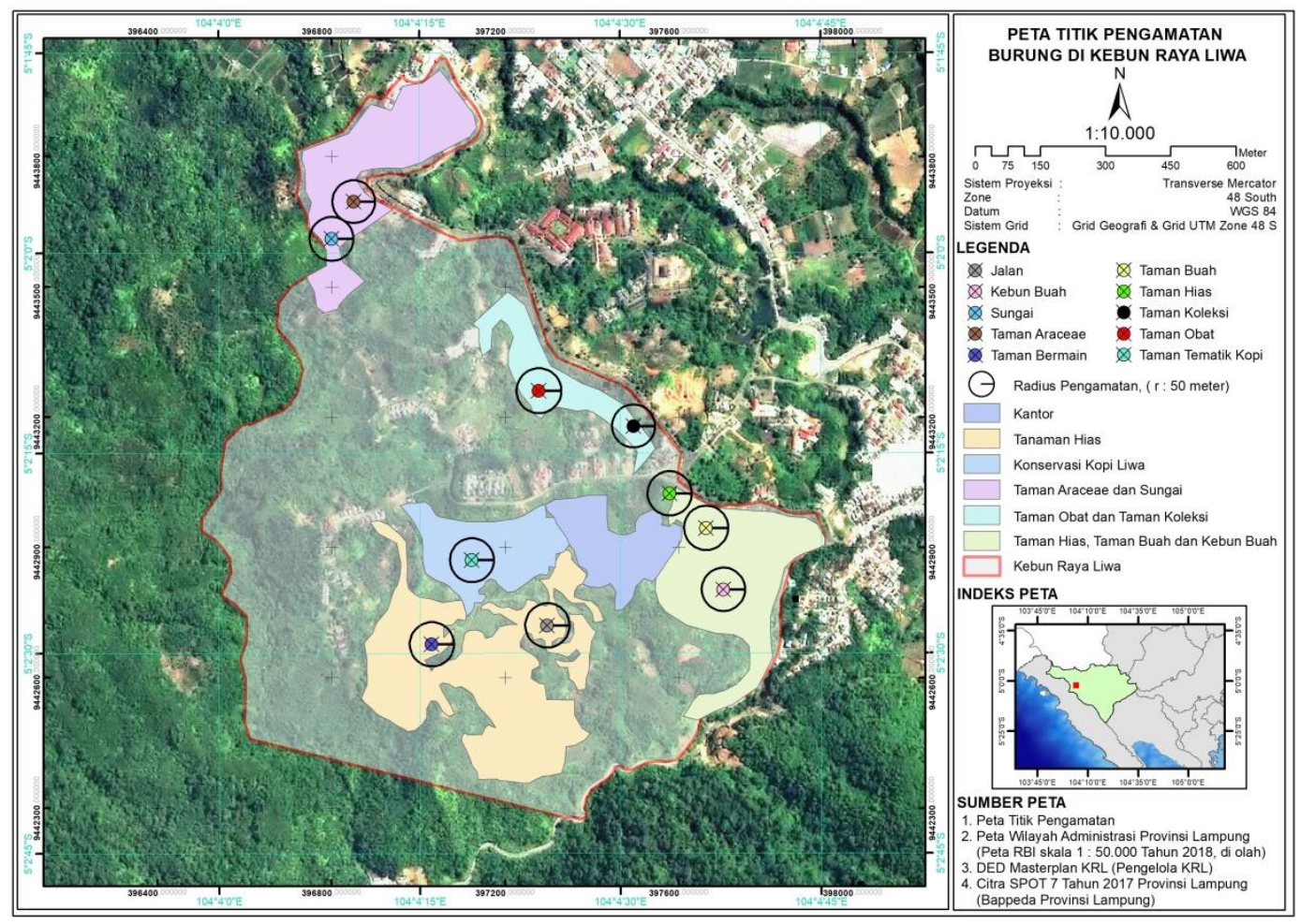

Gambar 1. Lokasi KRL

Figure 1. Location of Liwa Botanical Garden

Metode yang digunakan pada penelitian ini adalah ponit count. Kegiatan pengamatan menggunakan 10 titik hitung (point count) yang terletak pada 8 taman tanaman, jalan menuju taman bermain dan di daerah perbatasan antara KRL dan Taman Nasional Bukit Barisan Selatan. Radius pengamatan yang dugunakan pada metode point count adalah sejauh 50 meter, jarak pengamatan antar titik point count adalah 100 meter dengan waktu perpindahan antara titik satu ketitik lainnya (kurang lebih) 10 menit, lama pengamatan pada tiap titik point count adalah 20 menit. Pengamatan dilakukan selama 3 hari, pada pagi dan sore hari karena pada waktu tersebut adalah waktu burung aktif melakukan aktivitas, sehingga peluang besar untuk teramati. Waktu pengamatan dilakukan pukul 06.00 - 09.00 WIB dan sore hari pukul 15.00 - 18.00 WIB dengan cara diam pada titik yang sudah ditentukan kemudian mengamati dan mencatat perjumpaan setiap jenis burung yang terlihat. Layout point count yang digunakan pada penelitian ini dapat dilihat pada gambar 2 .

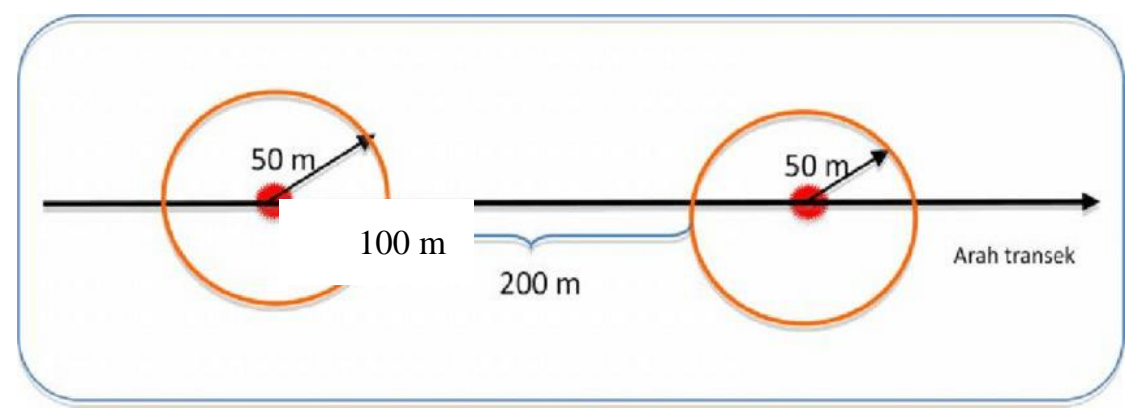

Gambar 2. Desain point count

Figure 2. Design of point count 
Burung yang teramati kemudian dicatat jenis dan jumlah individunya, identifikasi dan pencatatan jenis burung dilakukan pada setiap pertemuan dengan burung secara visual termasuk jenis yang sedang terbang (Iswandaru et al., 2018) serta melalui suara (Muhammad et al., 2018). Selanjutnya dikelompokkan berdasarkan kelompok pakannya. Kelompok pakan merujuk pada Rumblat et al. (2016), sedangkan identifikasi spesies burung merujuk pada MacKinnon et al. (2010) dan tata nama berdasarkan Sukmantoro et al. (2007).

Pada penelitian yang dilakukan oleh Rumblat (2016), ditemukan 6 tipe guild pakan. Untuk wilayah DKI Jakarta, kelompok burung pemakan serangga ini dikembangkan dalam 5 tipe guild dan pemakan daging dikembangkan menjadi 3 tipe guild sehingga diperoleh 12 tipe guild pakan. Untuk KRL diperingkas menjadi 6 tipe guild, yang mana untuk kelompok burung pemakan serangga dikembangkan menjadi 4 tipe guild dan pemakan daging dikembangkan menjadi 1 tipe guild. Data tersebut dapat dilihat pada Tabel 1.

Tabel 1.Guild pakan komunitas burung Table 1. Feeding Guilds of Bird Community

\begin{tabular}{cl}
\hline No & \\
\hline 1 & Pemakan serangga Tipe Guild \\
& 1.1 Pemakan serangga dengan meyambar \\
& 1.2 Pemakan serangga dengan melubangi kayu \\
& 1.3 Pemakan serangga di ranting \\
& 1.4 Pemakan serangga sambil terbang \\
& Pemakan daging \\
& 2.1 Pemangsa/predator \\
3 & Pemakan buah \\
5 & Pemakan biji \\
6 & Pemakan nektar \\
\hline
\end{tabular}

Sumber : Rumblat et al., (2016)

Berikut penjelasan deskripsi tipe guild pakan yang ditemukan di $\mathrm{KRL}$ :

Pemakan serangga (Insectivore).

Pemakan serangga dengan menyambar.mangsa (flycathing)

Kelompok burung yang berburu serangga dengan cara menyambar mangsanya diantara tajuk pohon kemudian hinggap untuk mencari mangsa selanjutnya.

Pemakan serangga di kayu/batang.

Kelompok burung yang mencari makan seperti serangga dengan cara melubangi kayu atau mencari dibawah kulit kayu yang sudah mati.

\section{Pemakan serangga di ranting pohon.}

Kelompok burung yang menjadikan serangga termasuk larva serangga sebagai pakan, yang didapatkan dengan cara hinggap dan melompat diantara cabang pohon.

\section{Pemakan serangga sambil terbang (Aereal Sreening).}


Kelompok burung yang menghabiskan hampir seluruh waktunya beraktivitas di udara untuk terbang dan mencari makan dengan cara menangkap serangga sebagai makanannya.

\section{Pemangsa dan predator (Carnivore).}

Kelompok burung pemangsa yang menjadikan hewan vertebrata seperti amfibi, reptil, burung-burung kecil, dan mamalia kecil sebagai makanannya. Memiliki ciri umum yaitu paruh berkait dan cengkraman cakar yang kuat untuk mencabik dan membunuh mangsanya.

\section{Pemakan buah (Frugivor).}

kelompok burung yang menjadikan buah matang yang memiliki tekstur lunak dan berukuran kecil sebagai makanannya, contohnya buah dari tanaman beringin.

\section{Pemakan biji (Granivoree).}

Kelompok burung yang memiliki bentuk paruh yang lebih tebal dan keras, digunakan untuk memecah biji. Dapat dijumpai pada areal yang ditumbuhi ilalang dan rerumputan penghasil buah berupa biji.

\section{Pemakan nektar (Nectarivore).}

kelompok burung dengan ciri fisik paruh panjang dan berukuran kecil khas burung pemakan nektar, termasuk semua jenis dari suku Nectarinidae.

\section{Pemakan pakan campuran (Omnivore).}

Kelompok burung yang memakan lebih dari satu tipe guild seperti campuran buah-buahan, pucuk tanaman, biji-bijian, dan beberapa jenis invertebrata.

\section{Analisis Data}

Hasil-hasil yang diperoleh kemudian dianalisis menggunakan metode analisis deskriptif berdasarkan variabel jenis burung yang dijumpai berdasarkan komposisi guild. Analisis deskriptif bertujuan untuk memberikan penjelasan berupa uraian berdasarkan data dan informasi yang diperoleh selama penelitian (Sitanggang et al, 2020).

\section{HASIL DAN PEMBAHASAN}

Tercatat sebanyak 41 jenis burung dari 21 famili yang teramati. Hasil ini menunjukkan bahwa KRL menjadi habitat untuk beberapa jenis burung, sedikitnya terdapat 3 jenis burung yang paling mendominasi berdasarkan jumlah perjumpaan saat pengamatan, diantaranya adalah Pycnonotus aurigaster (22,81\%), Collocalia esculenta (22,18\%), dan Macropygia ruficeps $(9,12 \%)$. Ketiga jenis burung tersebut sangat umum ditemukan di setiap lokasi pengamatan di KRL. Data persebaran burung di KRL dapat dilihat pada Tabel 2.

Tabel 2. Persebaran jenis burung

Table 2. Distribution of birds species

\begin{tabular}{|c|c|c|c|c|c|c|c|c|c|c|c|c|c|}
\hline \multirow{2}{*}{ No } & \multirow{2}{*}{ Nama } & \multirow{2}{*}{ Famili } & \multirow{2}{*}{ Jumlah } & \multicolumn{10}{|c|}{ Titik } \\
\hline & & & & 1 & 2 & 3 & 4 & 5 & 6 & 7 & 8 & 9 & 10 \\
\hline 1 & Bentet kelabu & Lanius schach & 53 & $\sqrt{ }$ & $\sqrt{ }$ & $\sqrt{ }$ & $\sqrt{ }$ & $\sqrt{ }$ & $\sqrt{ }$ & $\sqrt{ }$ & $\sqrt{ }$ & $\sqrt{ }$ & $\sqrt{ }$ \\
\hline 2 & Bondol haji & Lonchura maja & 13 & & & & $\sqrt{ }$ & $\sqrt{ }$ & & $\sqrt{ }$ & & & $\sqrt{ }$ \\
\hline
\end{tabular}

[199] This work is licensed under a Creative Commons Attribution 4.0 International License 
Jurnal Belantara Vol. 4, No 2, Agustus 2021 (195-206)

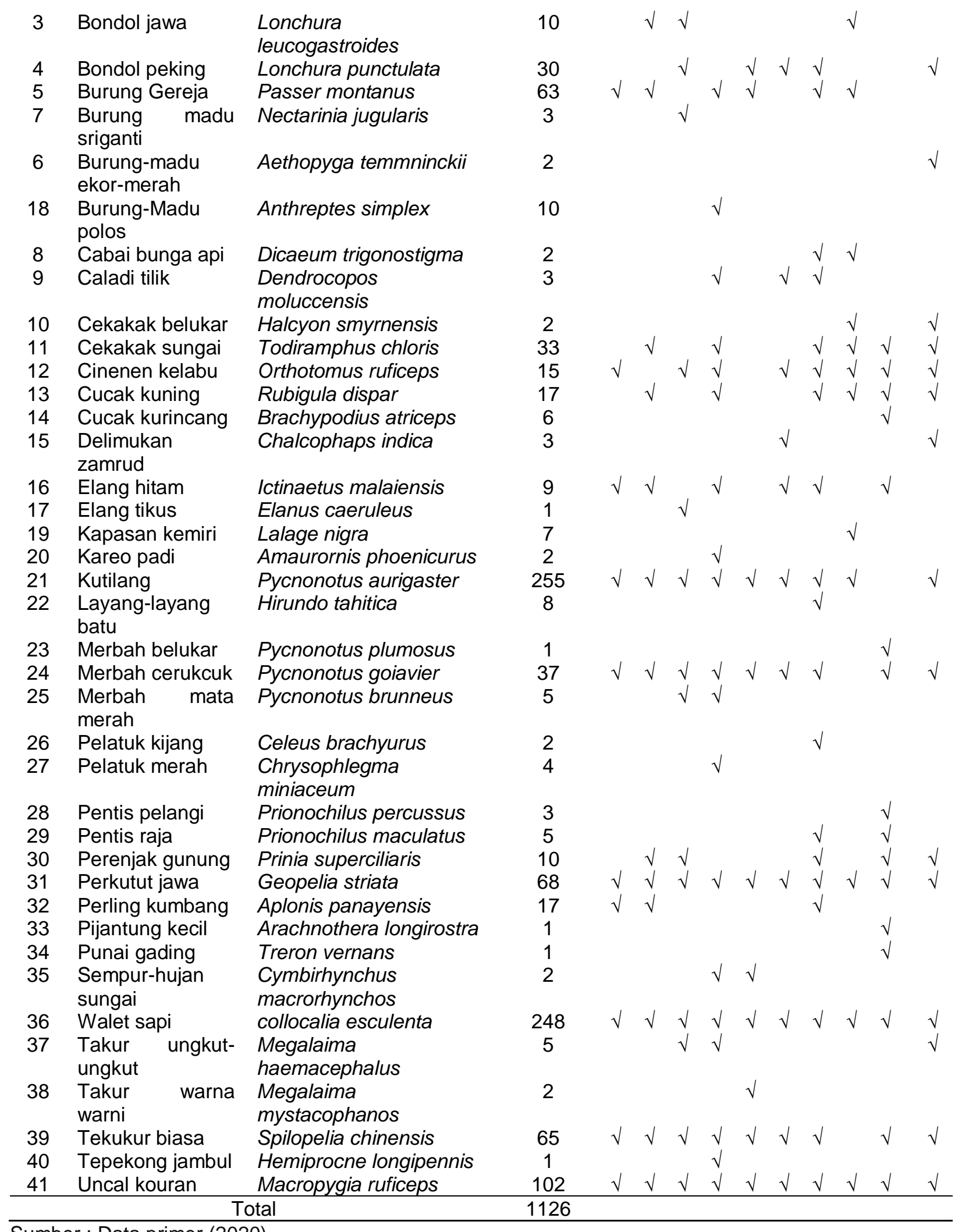

Sumber : Data primer (2020) 
Terdapat 6 kelompok pakan yang ditemukan di KRL dimana untuk burung pemakan serangga di kembangkan menjadi 4 tipe guild sehingga diproleh 9 tipe guild pakan, dapat dilihat pada Tabel 1. Tipe guild yang paling banyak adalah tipe burung pemakan buah. Burung yang teramati di KRL kemudian dikelompokkan ke masing-masing guild pakannya dan tersaji pada Tabel 3.

Tabel 3. Guild pakan 41 jenis burung di KRL

Table 3. Feeding guilds of 41 birds in Liwa Botanical Gardens.

\begin{tabular}{l} 
Pemakan serangga dengan menyambar $\mathbf{n = 3}(\mathbf{2 7 \% )}$ \\
Betet kelabu Lanius schach \\
Kapasan kemiri Lalage nigra \\
Perenjak gunung Prinia cuculatus \\
\hline Tabel 3. Lanjutan \\
Table 3. Continuous.
\end{tabular}

Pemakan serangga dengan melubangi kayu $\mathbf{n}=\mathbf{3}$

Caladi tilik Dendrocopos moluccensis

Pelatuk kijang Celeus brachyurus

Pelatuk merah Picus miniacues

Pemakan serangga di ranting $\mathrm{n}=\mathbf{2}$

Cinenen kelabu Orthotomus ruficeps

Sempur hujan sungai Cymbirhynchos macrorhyncho

Pemakan seangga sambil terbang $\mathbf{n}=\mathbf{3}$

Layang-layang batu Hirundo tahitica

Walet sapi Collocalia esculenta

Tapekong jambul Hemiprocne longipennis

Pemangsa/predator $n=4$ (10\%)

Cekakak belukar Halcyon smyrnensis

Cekakak sungai Todiramphus chloris

Elang tikus Elanus caeruleus

Elang hitam Ictinaetus malaiensis

Pemakan buah $\mathrm{n}=13$ (32\%)

Cabai bunga api Dicaeum trigonostigma

Pentis raja Prionochilus maculatus

Pentis pelangi Prionochilus percussus

Cucak kuning Pycnonotus melanicterus

Cucak kurincang Pycnonotus articeps

Cucak kutilang Pycnonotus aurigaster

Merbah cerukcuk Pycnonotus goiavier

Merbah belukar Pycnonotus plumosus

Merbah mata merah Pycnonotus brunneus

Perling kumbang Aplonis panayensis

Punai gading Treron vernans

Takur ungkut-ungkut Psilopogon haemacephalus

Takur warna warni Megalaima mystacophanos

Pemakan biji $\mathrm{n}=8$ (19\%)

Bondol haji Lonchura maja

Bondol jawa Lonchura leucogastroides

Bondol peking Lonchura punctulata 
Burung gereja eurasia Passer montanus

Perkutut jawa Geopelia striata

Tekukur biasa Spilopelia chinensis

Delimukan zamrud Chalcophaps indicaa

Uncal kouran Maropygia ruficeps

\section{Pemakan nektar $\mathrm{n}=4$ (10\%)}

Pijantung kecil Arachnothera longirostra

Madu polos Anthreptes simplex

Madu sriganti Nectarinia jugularis

Madu ekor merah Aethopyga temminckii

Pemakan pakan campuran $n=1(2 \%)$

kareo padi Amaurornis phoenicurus

Keterangan $\mathrm{n}=$ jumlah burung

Guild pakan jenis burung di KRL cukup bervariasi, setidaknya ada 6 jenis guild pakan yang dapat dijumpai yaitu carnivore, frugivor, granivoree, nectarivore, omnivore, dan insectivore. Untuk guild pakan insectivore dibagi menjadi 4 tipe berdasarkan cara berburu mangsanya antara lain pemakan serangga dengan cara menyambar mangsanya, melubangi kayu/batang pohon, mencari makan dicabang/ranting pohon dan menangkap serangga dengan cara terbang, selain pemakan serangga juga ada predator, pemakan buah, pemakan biji, pemakan nektar dan pemakan campuran, sehingga diperoleh 9 tipe guild pakan yang menjadi indikasi bahwa lokasi tersebut merupakan tempat yang sesuai menjadi habitat bagi berbagai jenis burung, karena menurut Rohiyan et al., (2014), burung memilih habitat yang mempunyai kelimpahan sumberdaya untuk kelangsungan hidupnya.

Masing-masing kelompok burung mempunyai jumlah yang berbeda-beda, perbedaan jumlah jenis burung setiap kelompok pakan dipengaruhi oleh sumber daya pakan yang tersedia. Hal tersebut menunjukkan bahwa setiap guild pakan memiliki respon berbeda terhadap kondisi suatu lingkungan. Menurut Nugroho et al. (2013), tipe habitat yang berbeda-beda akan berpengaruh terhadap keanekaragaman berbagai jenis burung. Habitat yang beragam mampu menyediakan sumberdaya yang cukup, sebagai tempat bagi burung untuk mencari makan, berlindung, berkembang biak (Hidayat dan Dewi, 2017).

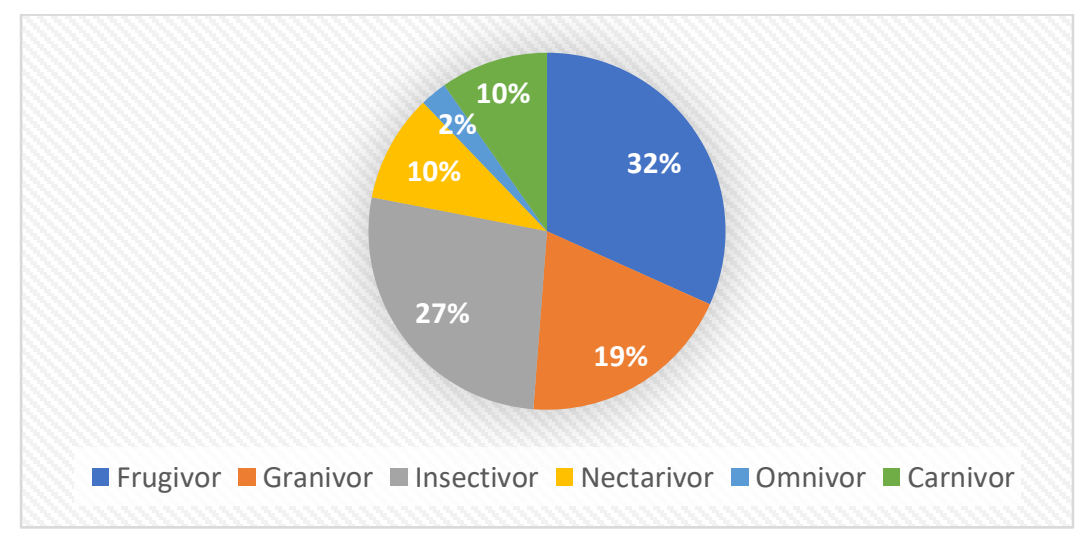

Gambar 2. Komposisi kelompok pakan di KRL

Figure 2. Compotition of feeding guild in Liwa Botanical Garden 
Gambar 2 menunjukkan bahwa burung-burung di KRL didominasi oleh burung frugivor sebanyak (32\%) yang didominasi oleh burung dari famili pycnonotidae yang ada di semua lokasi, hal tersebut dapat terjadi karena terdapat jenis-jenis pohon yang menghasilkan buah seperti berbagai jenis jambu-jambuan, sawo, nangka, dan markisa yang tersebar di beberapa lokasi, sehingga menarik perhatian burung frugivor untuk datang dan mencari makan. Meskipun tidak dapat disimpulkan bahwa seluruh jenis burung yang ada di KRL mencari makan hanya di KRL saja, namun sebagai habitat secara umum, KRL menjadi habitat yang baik bagi burung dalam menopang keberlanjutan masing-masing spesiesnya. Burung frugivor berperan penting bagi suatu ekosistem karena kelompok burung ini mempunyai fungsi sebagai penyebar biji tingkat pertama (Kunz et al., 2008).

Burung carnivore merupakan pemangsa puncak dalam rantai makanan (Prawiradilaga et al., 2002). Di KRL jenis ini ditemukan dalam jumlah kecil (10\%), hal tersebut terjadi karena beberapa faktor, seperti ketersediaan pakan yang terbatas dan home range burung pemangsa yang cukup luas sehingga memungkinkan jenis burung carnivore mencari makan ditempat lain dan $\mathrm{KRL}$ juga selain menjadi tempat mencari makan bisa juga menjadi tempat singgah sementara. Karena apabila suatu wilayah yang sering dikunjungi burung tersebut bisa disebabkan bahwa habitat tersebut dapat mensuplai makanan, minuman serta fungsi lainnya (Alikodra, 2002; Anugrah et al., 2017). Jenis burung elang atau raptor masih bisa dijumpai di $\mathrm{KRL}$ walaupun dalam jumlah dan jenis yang terbatas. Setidaknya ada dua jenis burung elang yang teramati yaitu burung elang hitam (Ictinaetus malaiensis) yang terlihat sedang melakukan aktifitas terbang (gliding), gliding adalah aktivitas terbang meluncur secara horizontal tanpa mengepakan sayap dalam jarak yang jauh, dan elang tikus (Elanus caeruleus) yang terlihat hinggap di atas pohon mati sedang memakan seekor tikus.

Faktor yang mendukung kehadiran burung pemangsa ini adalah lokasi KRL yang berdekatan dan berbatasan langsung dengan kawasan TNBBS yang berada di daerah perbukitan. Menurut widodo (2013), ketinggian tempat dapat mempengaruhi persebaran jenisjenis burung. Semakin tinggi lokasi habitat, semakin menurun keragaman jenis burung di dalamnya, karena hanya spesies burung tertentu saja yang mampu bertahan, salah satunya burung elang yang memanfaatkan perbukitan sebagai tempat untuk bersarang dan berkembang biak Nainggolan (2019). Selain burung elang ditemukan jenis burung pemangsa lain dari famili alcedinidae yaitu cekakak sungai (Todiramphus chloris) dan cekakak belukar (Halcyon smyrnensis). Burung cekakak lebih sering dijumpai dari pada burung elang karena cekakak dikategorikan sebagai burung umum yaitu yang paling mudah ditemukan di lokasi. Menurut Nur et al. (2013), penyebab suatu jenis burung dikatakan sebagai burung umum karena mampu beradaptasi terhadap perubahan kondisi habitat dan mampu berkompetisi dengan jenis burung lain dalam mencari makanan, selain itu home range burung cekakak tidak terlalu luas, dan jenis pakannya relatif lebih bervariasi dari pada burung elang. Biasanya burung cekakak berdiri mengamati mangsa dari atas dahan pohon (Kurniawan et al., 2017).

Kelompok burung nectarivore, jumlah perjumpaanya sama dengan burung carnivore (10\%). Hal tersebut dapat terjadi karena kelompok burung ini bergantung pada tanaman berbunga. Pembungaan tanaman di KRL hanya terjadi pada musim-musim tertentu dan juga dipengaruhi oleh jumlah serta persebaran jenis tanaman berbunga di lokasi penelitian, sehingga untuk dapat mengamati burung nectarivore dapat di sesuaikan pada waktu pembungaan tanaman. Hal ini sesuai dengan pernyataan Pauw dan Louw (2012), untuk menarik perhatian burung nectarivore adalah memilih tanaman penghasil bunga berdasarkan waktu mekar pembungaannya,sehingga dapat menyediakan nektar sepanjang tahun . 
Kelompok burung granivoree umumnya tidak menyukai habitat dengan tutupan kanopi yang rapat dan pepohonan tinggi (Cantebury et al., 2000). kelompok burung ini lebih memilih tegakan terbuka sebagai tempat untuk beraktifitas dan mencari makan. Delapan jenis burung ditemukan dari tiga famili berbeda yang terdapat di semua area pengamatan, namun tidak semua titik memiliki jumlah perjumpaan yang sama. Ada tiga jenis dari satu famili yang sama teramati di taman Araceae dan tiga jenis dari tiga famili berbeda dijumpai di area perbatasan antara Taman Nasional Bukit Barisan Selatan dan KRL. Kedua lokasi tersebut adalah tempat yang paling sedikit ditemukannya jenis burung granivoree, karena tutupan lahan yang cukup rapat dan didominasi pohon-pohon tinggi sehingga tidak dapat dijadikan tempat yang sesuai untuk mencari makan.

Perjumpaan terhadap jenis-jenis burung insectivore termasuk yang paling banyak ditemukan setelah burung-burung frugivor, ada 11 jenis burung dari sembilan famili yang dibagi dalam empat tipe guild burung insectivore, dengan cara berburu yang berbeda-beda saat mencari makan antara lalin: dua jenis pemakan serangga dengan menyambar mangsanya, tiga jenis dengan cara melubangi kayu, tiga jenis berburu serangga dengan cara terbang biasanya memiliki gaya terbang khas saat berburu serangga. Beberapa kelompok burung pemakan serangga memiliki pola terbang tertentu untuk menambah keefektifitasannya saat berburu pakan (Wong, 1986; Rumblat et al., 2020).

Kelompok pakan yang paling sedikit perjumpaanya adalah burung omnivore $(2 \%)$ karena hanya tercatat satu jenis burung yaitu burung kareo padi (Amourornis pheoenicurus) yang sedang beraktifitas mencari makan di sekitar jalan menuju taman bermain atau di titik empat, dimana lokasi tersebut terdapat aliran air yang menggenang dan ditumbuhi oleh tanaman bawah dan semak belukar. Kareo padi dapat ditemukan pada habitat kebun atau ladang. Burung kareo padi memiliki kebiasaan mencari makan pada kawasan sawah, payau atau kawasan perairan tawar (Kamal et al., 2016). Menurut pengamatan yang dilakukan oleh Hidayat dan Dewi (2017) kareo padi ditemukan dibawah sawit dan semak-semak. Sehingga dapat disimpulkan bahwa kondisi lahan di KRL menjadi habitat yang sesuai untuk burung kareo padi bersarang dan mencari makan.

\section{KESIMPULAN DAN SARAN}

Burung yang dapat ditemukan di KRL yaitu 41 spesies dari 21 famili dengan enam tipe guild pakan. Kelompok burung frugivore memiliki jumlah spesies yang paling dominan yaitu $32 \%$, yang dikuti dengan kelompok burung insectivore $27 \%$, granivore $19 \%$, nectarivore dan carnivore masing-masing 10\%, sementara kelompok burung omnivore memiliki jumlah spesies yang paling sedikit yaitu $2 \%$. KRL menyediakan habitat yang baik untuk mendukung kehidupan burung liar yang tergambar dari rantai makanan berdasarkan kelompok pakannya. Keberadaan enam tipe guild (kelompok pakan) burung di KRL perlu dipertahankan dengan menjaga daya dukung habitat melalui pemeliharaan dan pengkayaan tumbuhan sebagai sumber pakan.

\section{DAFTAR PUSTAKA}

Alikodra, H.S. 2002. Teknik Pengelolaan Satwa Liar. Buku. Yayasan Penerbit Fakultas Kehutanan IPB. Bogor.368 hlm.

Anugrah, K.D., Setiawan, A. dan Master, J. 2017. Keanekaragaman spesies burung di Hutan Lindung Register 25 Pematang Tanggang Kabupaten Tanggamus Lampung. Jurnal Sylva Lestari, 5(1),105-116. 
Firdaus, A. B., Setiawan, A., dan Rustiati, E.L. 2014. Keanekaragaman spesies burung di Repong Damar Pekon Pahmungan Kecamatan Pesisir Tengah Krui Kabupaten Lampung Barat. Jurnal Sylva Lestari, 2(2), 1-6.

Iskandar BS, Iskandar J, Partasasmita R. 2019. Hobby and business on trading birds: Case study in bird market of Sukahaji, Bandung, West Java and Splendid, Malang, East Java (Indonesia). Biodiversitas, 20(5), 1316-1332.

Iswandaru, D., Khalil, A.R.A., Kurniawan, B., Permana, R., Febryano, I.G. dan Winarno, G.D. 2018. Kelimpahan dan keanekaragaman jenis burung di Hutan Mangrove KPHL Gunung Balak. Indonesian Journal of Conservation, 7(1), 57-62.

Iswandaru, D., Febryano, I.G., Santoso, T., Kaskoyo, H., Winarno, G.D., Hilmanto, R., Safe'i, R., Darmawan A. dan Zulfiani D. 2020. Bird community structure of small islands: a case study on the Pahawang Island, Lampung Province, Indonesia. Silva Balcanica, 21(2), 518.

Iswandaru, D., Novriyanti, Banuwa, I.S. Harianto, S.P. 2020. Distribution of bird communities in University of Lampung, Indonesia. Biodiversitas, 21(6), 2629-2637.

Hasibuan, R. A., Nitibaskara, T. U., dan Mahadika, R. 2018. Jalur interpretasi birdwatching di Kebun Raya Bogor. Media Konservasi, 23(1), 28-36.

Hidayat, A. dan Dewi. B. S. 2017. Analisis keanekaragaman jenis burung air di Divisi I dan Divisi II PT.Gunung Madu Plantations Kabupaten Lampung Tengah Provinsi Lampung. Jurnal Sylva Lestari, 5(3), 30-38.

Kamal, S., Agustina, E. dan Rahmi, Z. (2016). Spesies burung pada beberapa tipe habitat di Kecamatan Lhoknga Kabupaten Aceh Besar. Jurnal Biotik, 4(1),15-32.

Kebun Raya Liwa. 2017. Buku Profil Kebun Raya Liwa. Liwa. Kebun Raya Liwa. 112 hlm.

Kiros, S., B. Afework, K. Legese. 2018. A preliminary study on bird diversity and abundance from Wabe fragmented forest around Gubre Subcity and Wolkite Town, Southwestern Ethiopia. -International Journal of Avian \& Wildlife Biology, 3(5), 333-340.

Kurniawan, E., Harianto, S.P. dan Rusita. 2017. Studi wisata burung (birdwatching) di lahan basah desa Kibang Pacing kecamatan Menggala Timur kabupaten Tulang Bawang Provinsi Lampung. Jurnal Sylva Lestari, 5(1), 35-46.

Mackinnon J, Philipps K dan Van Ballen A. 2000. Burung-burung di Sumatra, Jawa, Bali, dan Kalimantan. Puslitbang Biologi LIPI. Jakarta.

Muhammad, G.I., Mardastuti, A. Dan Sunarminto, T. 2018. Keanekaragaman jenis dan kelompok pakan avifauna di Gunung Pinang, Kramatwatu, Kabupaten Serang, Banten. Jurnal Media Konservasi. 23(2),178-186.

Novarino, W., Mardiastuti, A., Prasetyo, L.B., Widjakusuma, R., Mulyani, Y.A., Kobayashi, H., Salsabila, A., Jarulis dan Janra, M.N. 2008. Komposisi guild dan lebar relung burung strata bawah di Sipisang, Sumatera Barat. Biota. 13(3), 155-162. 
Olabamiyo, O.E. dan Akinpelu, A.I. 2015. Avian diversity and feeding guilds within lekki conservation center, Lagos State, Nigeria. International Journal of Science and Research (IJSR). 6(10), 724-729. DOI: 10.21275/ART20177073.

Paramita, E. C., Kuntjoro, S., \& Ambarwati, R. 2015. Keanekaragaman dan kelimpahan jenis burung di Kawasan Mangrove Center Tuban. Lenterabio. 4(3), 161-167.

Rohiyan, M. Setiawan, A. Dab Rustiati E.K. 2014. Keanekaragaman jenis burung di hutan pinus dan hutan campuran Muarasipongi Kabupaten Mandailing Natal Sumatera Utara. Jurnal Sylva Lestari. 2(2), 89-98.

Rumblat, W., Mardiastuti, A. Mulyani, Y.A. 2016. Guild pakan komunitas burung di dki jakarta. Media Konservasi, 21(1), 58-64.

Sari, I.F., Nurcahyani, N., Kanedi, M. dan Tugiyono. 2020. Bird species diversity in liwa botanical garden, west lampung Jurnal IImiah Biologi Eksperimen dan Keanekaragaman Hayati, 7(1), 1-6.

Sitanggang, F.I., Budiman, M.A.K., Afandy, A. dan Prabowo, B. 2020. Komposisi guild burung pada hutan sekunder termodifikasi di Curup Tenang Kabupaten Muara Enim Sumatera Selatan. Jurnal Biologica Samudra. 2(1), 66 - 78

Sukmantoro W, Mohammad I, Wilson N, Ferry H, Neville K, Muchamad M. (2007). Daftar Burung Indonesia No. 2. Indonesian Ornithologist' Union, Bogor.

Tesfahunegny, W., T. Fekensa, G. Mulualem. (2016). Avifauna diversity in Kafa Biosphere Reserve: Knowledge and perception of villagers in Southwest Ethiopia. - Ecology and Evolutionary Biology, 1(2), 7-13.

Winara A. (2016). Keragaman jenis burung air di Taman Nasional Wasur, Merauke. Jurnal Hutan Tropis 4(1), 85.

Wulandari, N.,Winarno, G.D., Setiawan, A., dan Darmawan, A. (2019). Persepsi wisatawan terhadap objek daya tarik wisata di KRL Kabupaten Lampung Barat. Jurnal Belantara. 2(2), 84-93.

Wong M. (1986). Trophic organization of understory birds in a Malaysian dipterocarp forest. Auk. 103: 100116. 